\title{
Cikkismertetés: Digitális Egészségműveltség-mérő Eszköz fejlesztése
}

\author{
Article review: Development of the Digital Health Literacy Instrument
}

Ismertető: $\quad$ Varga Szabolcs $\square$

Debreceni Egyetem Népegészségügyi Kar, Megelöző Orvostani Intézet

Ismertetett cikk: van der Vaart R, Drossaert C. Development of the Digital Health Literacy Instrument: Measuring a Broad Spectrum of Health 1.0 and Health 2.0 Skills. J Med Internet Res. 2017 Jan; 19(1): e27. doi: 10.2196/jmir.6709,

Beküldve: $\quad$ 2019. 08. 06.

doi: $\quad$ 10.24365/ef.v60i4.501

Kulcsszavak: digitális egészségmúveltség készségek; eHealth-műveltség; mérés; validitás; teljesítményalapú mérőeszköz

Keywords: digital health literacy skills; eHealth literacy; measurement; validity; performancebased instrument

A bemutatott publikáció az igen rangos, szakterületén magasnak számító impakt faktorral rendelkező Journal of Medical Internet Research folyóiratban jelent meg. Célja egy 21 itemes, digitális egészségmúveltséget mérő skála megbízhatóságának és validitásának vizsgálata volt ${ }^{1}$.

Az egészségügyi ellátás digitalizálódásával egyre több, ehhez kapcsolódó internetalapú applikáció jelent meg az elmúlt években. Így az egészségügyi szolgáltatások megfelelő használatához kompetenciák széles köre vált szükségessé. Ezeket a képességeket digitális vagy e-egészségműveltségnek nevezzük. A jelenleg rendelkezésre álló eszközök, melyek a digitális egészségmúveltség szintjét mérik, az információszerzésre (Egészség 1.0 képességek) fókuszálnak, figyelmen kívül hagyva a hálózati interaktivitáshoz kapcsolódó képességeket (Egészség 2.0). A cikk szerzői új skálát dolgoztak ki, mely alkalmas az Egészség 1.0 és Egészség 2.0 kompetenciák teljes körének mérésére.

A Digitális Egészségműveltség-mérő Eszköz (Digital Health Literacy Instrument, DHLI) operatív, navigációs, információkeresés, megbízhatóság- és relevanciaértékelés, sajáttartalom-generálás és személyes adatbiztonság képességek mérését is magában foglalja. A DHLI-skála összesen 21 kérdésből áll (az angol nyelvű skála az eredeti közleményben megtalálható), melyekre válaszolva négy válaszlehetőség közül választhat a kérdezett. A lehetséges válaszok a „nagyon könnyü"-től a „nagyon nehéz"-ig, vagy a "soha” választól a „mindig” válaszig (1-4) terjednek, a kérdéstől függően. Az egyén pontszáma a kérdésekre adott válaszok pontértékének átlaga, abban az esetben, ha legalább 18 kérdésre válaszolt a kérdezett. A teljes skála 7 alskálából áll, melyek egy-egy kompetenciát vizsgálnak, és 3 kérdést tartalmaznak.

A szerzők papíralapú kérdőívet használtak a felmérés során, melyet Dániában kérdeztek le az általános populáció körében, önkitöltős módon. Életkor, nem és iskolai végzettség alapján rétegzett mintavételt alkalmaztak. A kérdőív tartalmazta a DHLI-skálát, kiegészítve szociodemográfiai, internethasználattal, egészségi állapottal és egészségmúveltséggel kapcsolatos változókkal, valamint az eHealth Literacy Scale (eHEALS) kérdéseivel. ${ }^{1}$ A mintavétel 
két különböző időpontban történt, a két időpont között 14 nap telt el $\left(n_{\mathrm{t} 1}=200\right.$ és $\left.n_{\mathrm{t} 2}=67\right)$. A második időpontban a kérdezettek csak a DHLI-skálát töltötték ki. A szerzők a skála belső konzisztenciáját Chronbach-alfa mutatóval jellemezték. A tartalmi és szerkezeti érvényességet főkomponens-elemzéssel és korreláció-analízissel vizsgálták. ${ }^{2}$

A válaszadók életkora 18 és 84 év között volt, 23\%-uk alacsony iskolai végzettséggel rendelkezett. A teljes skála belső konzisztenciája 0,87 volt a mintában, az alskálák Chronbach-alfa értékei pedig 0,70 és 0,89 között mozogtak. Ez alól kivételt jelent a személyi adatok védelme, az alskála alacsony belső konzisztenciát mutatott (0.57). A skála pontszáma megközelítőleg normál eloszlású volt. A főkomponens-elemzés (76\% magyarázott varianciával) megerősítette a skála elméleti szerkezetét. A skála eredménye gyengén korrelált az életkorral ( $r=-$ $0,41, p<0,001)$, végzettséggel $(r=0,14, p=0,047)$, internethasználattal $(r=0,39, p<0,001)$, egészséggel kapcsolatos internethasználattal $(r=0,27, p<0,001)$, egészségi állapottal $(r=0,17-0,27, p<0,001)$ és az egészségmúveltséggel $(r=0,31, p<0,001)$; közepes mértékben az eHEALS eredményével $(r=0,51$, $p<0,001)$.

A szerzők az eredmények alapján azt a konklúziót vonták le, hogy az eszköz alkalmas a digitális egészségmúveltség több szempontú és átfogó mérésére.

\section{TANULSÁGOK HAZAI SZAKEMBEREK SZÁMÁRA}

Az egészségműveltség mérésében új kihívást jelent a digitalizálódó egészségügyi ellátás, mivel annak megfelelő eléréséhez újabb és újabb kompetenciák válnak szükségessé. A jövőbeni kutatásoknak érdemes használniuk és vizsgálniuk a Digital Health Literacy Instrument megbízhatóságát és alkalmazhatóságát magyarországi mintavételekben a digitális egészségműveltség mérésére.

\section{TÁMOGATÁS}

A publikáció elkészítését a GINOP-2.3.2-15-2016-00005 számú projekt támogatta. A projekt az Európai Unió támogatásával, az Európai Regionális Fejlesztési Alap társfinanszírozásával valósult meg.

\section{HIVATKOZÁSOK}

\footnotetext{
${ }^{1}$ Norman CD, Skinner HA. eHEALS: The eHealth Literacy Scale. J Med Internet Res. 2006 Nov;8(4):e27.

${ }^{2}$ Klinikai Biostatisztikai Társaság. Biostat szótár. http://www.biostat.hu/biostat-szotar/
} 